\title{
Influence of climatic component upon productivity of stevia
}

\author{
Roik M., \\ Academician of the NAAS, Doctor of Agricultural Sciences \\ Institute of Bioenergetic Cultures and Sugar Beet NAAS \\ Kuznetsova I. Doctor of Agricultural Sciences \\ National Academy of Agrarian Sciences of Ukraine
}

The purpose. To determine influence of weather-climatic conditions upon phenological phases of development of overground part of stevia. Methods. Field and statistical, data of meteorological stations in Kiev, Vinnitsa and Ternopol for 2008 - 2016. Results. It is proved that weather environment for the period of probes influenced phenological phases of propagation and development of plants of stevia. Agrometeorological conditions of formation of yield of stevia based on interphase periods of development are analyzed, and heat and water provision of plants in the fixed interphase period is specified. Conclusions. The highest index of use of moisture in vegetative period was in Ternopol and Kiev oblasts, and quotient of water adsorption - in Kiev oblast. Statistical link is revealed of yield of overground part of stevia with the sum of efficient temperatures above $15^{\circ} \mathrm{C}$.

Key words: overground part, productivity, climatic component, phase of vegetative development.

Introduction. With the warming at latitudes where Ukraine is located, changes in the humidity regime and, accordingly, crop yields can occur. This leads to an aggravation of food and environmental problems, because of the changes in climatic and weather conditions, the activity of all parts of the agricultural sector depends on: "Climatic factors in our country are decisive in the problem of yield. They are stronger than the economy, stronger than the technology "[1].

Detection of the influence of the climatic component in the formation of the efficiency of stevia and the establishment of quantitative indicators that allow to characterize the size of its crops is an urgent problem.

Analysis of recent research and publications. For the establishment of quantitative relationships of crops with meteorological indicators, commonly used two approaches, based on which:

- indicators that characterize the most important stages in the life of plants during the growing season;

- conditions of heat and moisture of certain periods of plant development.

Quantitative relationships between crop yield and weather conditions are established for varieties most common in the studied area. In a permanent growing area, the yield of a certain culture has a tendency to increase and depends on the subzone of moisture. On the background of general yield growth, annual fluctuations are observed. The increase in yields contributes to the improvement of the culture of agriculture (the emergence of new productive varieties, soil treatment methods, fertilizer use, pest and disease control, etc. Annual yield deviations from its overall value are determined by the weather conditions of a given year. Thus, the following classes of factors are distinguished, influencing the crop crop: class 1 - determines the level of culture of agriculture, class 2 - meteorological factors [2, 3].

There is enough scientific work $[4,5]$ on the impact of the climatic component on the productivity of crops. But these works do not cover all crops and can not characterize the influence of weather climatic conditions during periods of vegetative development of such a plant as stevia.

Research methodology. Field studies on the influence of weather and climatic conditions on the yield of stevia of the Beregin species were carried out on research sites of experimental farms in Kyiv (State Enterprise «Agrofirma Veselinovka») during 2011-2016, in Vinnitsa (Marianivka village) during 2008-2016 in the regions of Ternopil (NeoKsvit LLC) during 2013-2016. According to the climatic conditions, the cultivation of stevia was carried out in sufficient subareas (Vinnytsia and Ternopil regions: $560-600 \mathrm{~mm}$ of precipitation, 
vegetation period $-380-450 \mathrm{~mm}$, the sum of temperatures above $10^{\circ} \mathrm{C}$ is $2300-2500^{\circ} \mathrm{C}, \mathrm{GTC}=1,3-1,5$ ) and unstable (Kyiv region: $\quad 480-500 \mathrm{~mm}, \mathrm{GTK}=1,0-1,1)$ humidification.

For studies on the influence of climatic conditions on the formation of stevia yields, materials of parallel observations of its yield and meteorological data of meteorological stations in Kyiv, Vinnytsia and Ternopil in the period from 2008 to 2016 [6] were used.

In the conditions of Vinnytsia region during 2008-2016 the temperature minimum necessary for vegetative development and formation of seed material was provided in: May - $12-17^{\circ} \mathrm{C}$, June $-17-20^{\circ} \mathrm{C}$, July - 20-22 ${ }^{\circ} \mathrm{C}$, August $-19-21^{\circ} \mathrm{C}$, September $-12-17^{\circ} \mathrm{C}$. Weather conditions in the Kiev region are more favorable than in the Vinnytsia region and have a higher temperature minimum necessary for vegetative development and seed formation in: May $-12-17^{\circ} \mathrm{C}$, June $-18-22^{\circ} \mathrm{C}$, July - 20-24 ${ }^{\circ} \mathrm{C}$ August - 20-22 ${ }^{\circ} \mathrm{C}$, September $15-17^{\circ} \mathrm{C}$. Conditions of the Ternopil region can also provide for vegetative development and are sufficient to obtain the proper level of the land surface harvest in: May $-12-17^{\circ} \mathrm{C}$, June $-15-20^{\circ} \mathrm{C}$, July $-18-20^{\circ} \mathrm{C}$, August $-18-20^{\circ} \mathrm{C}$, September $-12-15^{\circ} \mathrm{C}$.

An analysis of the weather conditions of the years of research has shown that they were quite contrasting and significantly different from the average long-term parameters. The metrological component is closely related to the yield of plants and is calculated according to formulas 1-6 [7].

Coefficient of heat supply $\left(\mathrm{K}_{m}\right)$ was calculated by the formula:

$$
\mathrm{K}_{\mathrm{T}}=\frac{\sum \mathrm{t}_{\phi}}{\sum \mathrm{t}_{\text {cep }}}
$$

where $\sum \mathrm{t}_{\phi}$ - the sum of temperatures of the interphase period, ${ }^{\circ} \mathrm{C}$,

$\sum \mathrm{t}_{\text {cep }}$ - average temperature of the period, ${ }^{\circ} \mathrm{C}$.

Coefficient of wet supply $\left(K_{B}\right)$ was calculated by the formula:

$$
\mathrm{K}_{\mathrm{B}}=\frac{\sum \mathrm{E}}{\sum \mathrm{E}_{0}},
$$

where $\sum E$ - the total water consumption of plants, $\mathrm{mm}$,

$\sum \mathrm{E}_{\mathrm{в}}$ - evaporation, $\mathrm{mm}$.

The heat use index $\left(I_{m}\right)$ was calculated by the formula:

$$
\mathrm{I}_{\mathrm{T}}=\frac{\sum \mathrm{t}}{\sum \mathrm{y}}
$$

where $\sum \mathrm{t}$ - amount of active temperatures, ${ }^{\circ} \mathrm{C}$,

$\sum \mathrm{y}$ - crop capacity, $\mathrm{t} /$ hectar.

Index of moisture usage on $1^{\circ} \mathrm{C}\left(\mathrm{I}_{8 \theta}\right)$ calculated according to the formula:

$$
\mathrm{I}_{\mathrm{BB}}=\frac{\sum \mathrm{R}}{\sum \mathrm{t}}
$$

where $\sum \mathrm{R}$ - amount of precipitation, $\mathrm{mm}$.

Water consumption coefficient $\left(K_{8 \varepsilon}\right)$ calculated according to the formula:

$$
\mathrm{K}_{\mathrm{dB}}=\frac{\sum \mathrm{R}}{\sum \mathrm{y}},
$$

Variability caused by the weather $\left(C_{m}\right)$, is determined by the variability of weather:

$$
C_{m}=\frac{1}{y} \sqrt{\frac{\sum_{i=1}^{n}\left(y_{i}-y_{c e p}\right)^{2}}{n-1}},
$$


where $y_{i}$ - yield of a certain year, $t /$ hectar;

$y_{\text {cep }}$ - average long-term yield, $t /$ hectar;

$y$ - dynamic average yield, t/hectar;

$\mathrm{n}$ - number of years.

Research results. According to our studies in stevia, the following periods of vegetative development of plants are distinguished: "seedlings - ladders" (35-40 days); "stairs - branching" (50-55 days); "branching And harvesting" (50-60 days); "Branching - II harvest" (50-60 days); "formation and maturation of seeds" (515 days). Since the seedlings are produced in the greenhouse and the roots are stored in the basement in the winter, studies on the effects of weather conditions on vegetative development are of interest to us: "stairs - branches" (planting of seedlings or roots in the soil - May 18-23 - May 30-02 June); "branching - And harvesting" (03 June - 09 July); "Branching - II harvest" (July 10 - September 20-25); "the formation and maturation of the seeds" (September 26 - October 10-20).

The results showed that weather conditions during the years of research significantly influenced the passage of phonological phases of growth and development of plants of stevia. Weather conditions, which formed in separate years of research, had a significant influence on the passage of phonological phases of growth and development of plants and their duration. Significant influence was on the distribution of precipitation during the growing season. The highest yield of stevia was formed according to the weather conditions of the Vinnitsa region in 2010, 2014 and 2016 and amounted to $2.4 \mathrm{t} /$ hectare. The yields in the Vinnitsa region in 2008, 2009, and 2011-2013 were slightly lower compared to $2015-2.3 \mathrm{t} /$ hectare. In Ternopol region, the highest yield was $2.4 \mathrm{t} /$ hectare in 2013-2014 and the lowest in 2015. In conditions of the Kiev region, the highest yield was $2.4 \mathrm{t} /$ hectare in 2012-2014 and 2016, the lowest $2.3 \mathrm{t} /$ hectare in 2011 and 2015. The relationship between yield and meteorological component was stronger in the subzone of unstable moisture and sufficient moisture (Ternopol region.) And weaker in the subzone of sufficient moisture (Vinnitsa region). The equation of the regression of the influence of weather conditions (y) on yield $(x)$ has the following form:

- Vinnitsa region $(y 1)-y 1=0,02 x+2,27$

- Ternopol region (y2) $-\mathrm{y} 2=0,05 \mathrm{x}^{3}-1,1 \mathrm{x}^{2}+7,95 \mathrm{x}-16,5$

- Kyiv region $(y 3)-y 3=0,002 x^{4}-0,05 x^{3}+0,37 x^{2}-1,12 x+3,34$.

The obtained regression equations show a significant influence of the weather conditions of the subzone humidification on changes in the yield of stevia. The calculation of the coefficients of the variation of the climatic component of stevia yield (Table 1) showed that the same weather conditions for plant cultivation were detected in the Vinnitsa and Kyiv oblasts, and the uneven weather conditions were in the Ternopol region.

Table 1 - Climatic component of variability of stevia crops for subzones of humidification

\begin{tabular}{|c|c|c|c|}
\hline \multirow{2}{*}{ Year } & \multicolumn{3}{|c|}{$\begin{array}{c}\text { Climatic component of the crop, } C_{m} \text { Sm } \\
\text { (factor A) }\end{array}$} \\
\cline { 2 - 4 } & A1 & A2 & A3 \\
\hline 2008 & 0,34 & - & - \\
\hline 2009 & 0,39 & - & - \\
\hline 2010 & 0,33 & - & 0,91 \\
\hline 2011 & 0,35 & - & 0,96 \\
\hline 2012 & 0,48 & - & 0,91 \\
\hline 2013 & 0,35 & 0,92 & 0,83 \\
\hline 2014 & 0,38 & 1,00 & 0,96 \\
\hline 2015 & 0,32 & 1,17 & 0,75 \\
\hline 2016 & 0,14 & 1,23 & 0,89 \\
\hline середнє & 0,34 & 1,08 & \\
\hline
\end{tabular}

Note: $\mathrm{A} 1$ is a subzone of sufficient moisture (Vinnitsa region), 
A2 - subzone of sufficient moisture (Ternopol region),

$\mathrm{A} 3$ is the subzone of unstable moisture (Kyiv region).

In all the years studied, there was an almost identical yield of stevia, which shows timely regulation of the elements of cultivation technology. It is noted that in one subzone grown stevia does not behave the same way. In particular, the smallest variability in the climatic component of yields is observed in the Vinnitsa region (0.34), the largest in the Ternopol region (1.08). In the conditions of the Kyiv region, the climatic component is also quite high and on average for 6 years is 0.89 .

Analyzed the agrometeorological conditions for the formation of stevia crops for interphase periods of development over the years studied, the mean values of which are presented in Table 2.

Table 2 - Average quantitative values of the main factors of productivity of stevia in the interphase periods of development

\begin{tabular}{|c|c|c|c|c|c|c|}
\hline \multicolumn{2}{|r|}{ factors } & \multirow{2}{*}{$\begin{array}{l}\text { Stairs - } \\
\text { the beginning } \\
\text { of branching }\end{array}$} & \multirow{2}{*}{$\begin{array}{l}\text { Guidance - } \\
\text { And } \\
\text { harvesting }\end{array}$} & \multirow{2}{*}{$\begin{array}{l}\text { Guidance - } \\
\text { II harvest }\end{array}$} & \multirow{2}{*}{$\begin{array}{c}\text { Formation } \\
\text { and maturation } \\
\text { of the seeds }\end{array}$} & \multirow{2}{*}{$\begin{array}{l}\text { Vegetati } \\
\text { ve period }\end{array}$} \\
\hline A & performance & & & & & \\
\hline \multirow{5}{*}{$1^{A}$} & Heat supply coefficient & 1,7 & 1,3 & 1,8 & 2,2 & 7,0 \\
\hline & Coefficient of humidity & 0,6 & 1,1 & 0,8 & 0,5 & 3,0 \\
\hline & Heat Index (at $\left.1^{\circ} \mathrm{C}\right)$ & 321,8 & 352,9 & 389,1 & 163,8 & 1227,6 \\
\hline & Index of moisture use & 0,5 & 1,1 & 1,1 & 2,5 & 5,2 \\
\hline & $\begin{array}{cc}\text { Water } & \text { consumption } \\
\text { coefficient } & \end{array}$ & 202,9 & 277,4 & 214,9 & 149,3 & 844,5 \\
\hline \multirow{5}{*}{$2^{\mathrm{A}}$} & Heat supply coefficient & 1,8 & 1,7 & 1,6 & 2,4 & 7,5 \\
\hline & Coefficient of humidity & 1,3 & 1,4 & 1,6 & 1,1 & 5,4 \\
\hline & Heat Index $\left(\right.$ at $\left.1^{\circ} \mathrm{C}\right)$ & 269,4 & 291,5 & 395,6 & 235,5 & 1192,0 \\
\hline & Index of moisture use & 1,7 & 1,3 & 1,7 & 3,8 & 8,5 \\
\hline & $\begin{array}{c}\text { Water } \\
\text { coefficient }\end{array}$ & 381,1 & 346,9 & 540,5 & 352,3 & 1620,8 \\
\hline \multirow{5}{*}{$3^{\mathrm{A}}$} & Heat supply coefficient & 1,7 & 1,6 & 1,3 & 2,3 & 6,9 \\
\hline & Coefficient of humidity & 0,7 & 1,0 & 2,3 & 0,5 & 4,5 \\
\hline & Heat Index $\left(\right.$ at $\left.1^{\circ} \mathrm{C}\right)$ & 253,4 & 364,9 & 376,1 & 157,4 & 1151,8 \\
\hline & Index of moisture use & 1,2 & 0,9 & 1,3 & 3,2 & 6,6 \\
\hline & $\begin{array}{cc}\text { Water } & \text { consumption } \\
\text { coefficient } & \end{array}$ & 360,3 & 343,3 & 468,8 & 399,6 & 1518,0 \\
\hline
\end{tabular}

Note: A1 is a subzone of sufficient moisture (Vinnitsa region),

A2 - subzone of sufficient moisture (Ternopol region),

$\mathrm{A} 3$ is the subzone of unstable moisture (Kyiv region).

The calculated coefficient of heat supply shows that in all subzone humidity in the interphase period of vegetative development of plants were sufficiently provided with heat. The highest index of heat utilization was in Vinnytsya Oblast (1227.6), the lowest in the Kyiv Oblast (1151.8).

According to the values of the water supply coefficients, it was noted that interphase periods for the subzone of sufficient moisture were problematic - "seeding is the beginning of branching" and "formation and receipt of seeds", and for the subzone of unstable moisture - after the I harvest ("branching - II harvest" and "the formation and maturation of seeds"). The highest index of moisture use was in Ternopil Oblast (8.5) and in the Kyiv Oblast (6.6). However, the highest coefficient of water consumption was in the Kiev region, which was 1518.0 during the growing season. 
Analyzing long-term data, it was noted that the index of moisture use is advantageously higher than the moisture content ratio. Consequently, plants do not fully absorb moisture necessary for vegetative development, which requires additional moisture in the subchronic zone.

The statistical connection of the crops of the above-ground part of stevia $(Y)$ with the sum of effective temperatures $(\mathrm{T})$ above $15^{\circ} \mathrm{C}$ for the critical period is described by the equation for the subzone:

$$
\begin{aligned}
& \text { sufficient moisture } \mathrm{Y}_{\text {дз }}=0,903 \times \sum \mathrm{T}-0,2 ; \\
& \text { unstable moisture } \mathrm{Y}_{\text {нз }}=0,401 \times \sum \mathrm{T}-0,97 \text {. }
\end{aligned}
$$

The correlation coefficients for the subzone of a sufficient moisture of 0.64 and unstable moisture is 0.98 . High values of the coefficients of correlation between the sum of temperatures and the yield of the aboveground part of stevia indicates the high requirements of plants to provide heat for vegetative development of plants.

\section{Conclusion}

It was established that in the investigated sub-regions the moistening of the vegetative stage of stevia "branching-Il flowering phase" and "formation and maturation of seeds" were drying. The smallest variability of the climatic component of stevia crops was observed in Vinnitsa oblast (0.34), the largest in Ternopol (1.08). According to the value of the heat supply coefficient, it was noted that in all sub-zones humidity in the interphase period of vegetative development of the plant was sufficiently provided with heat: the highest index of heat use was in the Vinnitsa region (1227.6), the lowest in the Kiev region (1151.8). It was noted that the highest index of moisture use during the growing season was in Ternopol region (8.5) and in Kiev (6.6), the highest coefficient of water consumption was in the Kiev region (1518.0). The statistical connection of crops of the above-ground part of stevia with the sum of effective temperatures above $15^{\circ} \mathrm{C}$ and correlation coefficients have been shown that vegetative development of the plant reveals high requirements for their provision with heat.

\section{Bibliography}

1. Синицына Н.И. Агрометеорология/Н.И. Синицына, И.А. Гольцберг, Э.А. Струнников. - Л.: Гидрометеоиздат, 1973. - $344 \mathrm{c.}$

2. Манелля А.И. О прогнозировании урожаев сельскохозяйственных культур по одномерному ряду/А.И. Манелля, А.А. Френкель//Зап. Ленинградского СХИ. - 1973. - Т. 207. — 53 с.

3. Барабаш М.Б. Дослідження змін та коливань опадів на рубежі XX і XXI ст. в умовах потепління глобального клімату/М.Б. Барабаш, Т.В. Корж, О.Г. Татарчук//Наук. праці УкрНДГМІ. - 2004. - Вип. 253. - C. $92-102$.

4. Балагура О.В. Вплив погодних умов на ріст, розвиток та продуктивність насінників цукрових буряків/ О.В. Балагура, В.М. Балан//Наук. gраці Ін-ту біоенергетичних культур і цукрових буряків HAAН. - 2015. - № 23. - С. $85-89$.

5. Клайн У.Р. Глобальное потепление и сельское хозяйство/У.Р. Клайн//Финансы и развитие. 2008. - C. $23-27$.

6. Израэль Ю.А. Моделирование влияния изменений климата на продуктивность сельского хозяйства России/Ю.А. Израэль, О.Д. Сиротенко//Метеорология и гидрология. — 2003. — № 6. - С. 5 -17 .

7. Climate-crop yield relationships at provincial scales in China and the impacts of recent climate trends/F. Tao, M. Yokozawa, J. Liu, Z. Zhang//Climate Research. - V. 38. - P. $83-94$.

8. Agricultural and Forest Meteorology/E.I. Teixeira, G. Fischer, Van Velthuizen H. et al. - 2013. - V. 170. - P. $206-215$.

9. Расписание погоды [Електр. pecypc] - http://rp5.ua/town.php?id=687\&lang=ru

10. Божко Л.Ю. Вплив погодних умов на формування продуктивності баклажанів в степовій зоні України/Л.Ю. Божко, О.А. Барсукова//Укр. гідромет. журн. - 2012. — № 11. — С. 163 - 169. 